\title{
THE EFFECT OF LIQUIDITY RISK ON BANK PERFORMANCE: MODERATING EFFECT OF BOARD SIZE
} AND BOARD MEETING

\author{
Indira Nuansa Ratri \\ Teknik Informatika, Politeknik Negeri Banyuwangi \\ Address: Jalan Raya Jember No.KM13, Kawang, Labanasem, Kec. Kabat, Kabupaten Banyuwangi, \\ Jawa Timur, Indonesia 68461 \\ E-mail: indira.nuansaratri@poliwangi.ac.id
}

\begin{abstract}
Bank performance is the most important thing to note and interesting to study because it plays a crucial role in a country's economy. This study aims to determine the effect of liquidity on bank performance and the moderating effect of the size and board meeting. The test in this study uses multiple linear regression on conventional banks listed on the Indonesia Stock Exchange from 2014 to 2019 . The results of this study indicate that liquidity has a positive effect on bank performance, the size of the board of commissioners weakens the positive effect of liquidity on bank performance, and the number of board meeting weaken the positive effect of liquidity on bank performance.
\end{abstract}

Keywords: Liquidity, bank performance, board size, board meeting

JEL Classification: G21, G28

Article History:

Received : October 5, 2021; Revised : November 15, 2021; Accepted : November 20, 2021; Available Online : December 12, 2021

DOI: $10.20473 / \mathrm{imtt.v14i3.30470}$

\section{INTRODUCTION}

The strength of the banking system is an important condition for ensuring the stability and growth of the national economy (Halling and Hayden, 2006). Banks are the main part of the financial sector in the economy that carries out activities as both distributors and collectors of funds for the public. Due to the function of the bank as an intermediary institution whose job is to collect public funds then distribute them to the credit, banks need to pay attention to both sides of the balance sheet, both on the asset side and on the liability side or commonly referred to as asset-liability management. In addition, banks also have a function to facilitate the payment system and support the expedited payment of goods and services. In carrying out its functions, banks also participate in helping to develop new industries through lending in order to increase employment opportunities and can also accelerate economic growth.

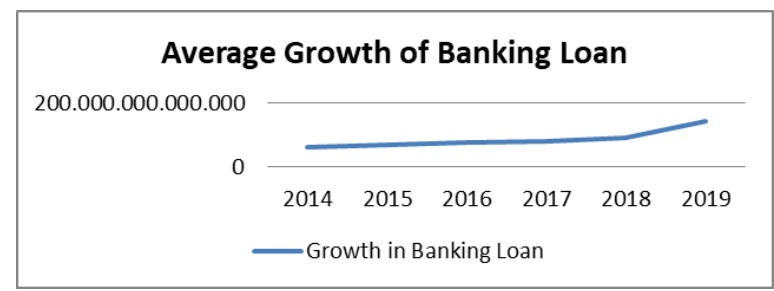

Chart 1.

Graph of average growth in bank lending 
The illustration in Chart 1 shows that the average number of loans disbursed by banks, especially in Indonesia, continues to increase. This also reflects that the Indonesians still use banks as the main source of funding in developing all industrial activities. This statement is supported by research conducted by Wijayanti and Mardiana (2020), proving that banks have increased lending. Banks also have a very crucial role in running and improving the economy. Based on the Indonesian Banking Survey (SPI), the increase in national banking loan growth occurred due to the strengthening of the economy, lower lending rates, more lenient lending policies, longer credit periods and cheaper credit approval fees (finance.detik.com).

The crucial function of the bank exposes the bank to liquidity risk. Liquidity risk is one of the risk components that greatly influences the performance of the banking industry. This is because liquidity risk affects the bank condition and greatly affects the level of public trust in the bank. Therefore, in order to support and maintain the performance of the banking industry, especially in Indonesia as a developing country where banks are still one of the main sources of funds that the public can reach to increase their business activities, it is important to optimize their liquidity to increase banking performance.

In maintaining their performance, banks not only pay attention to various aspects of risk that must be faced. In this case, the commissioners as supervisors and givers of consideration for each policy produced also contribute significantly in maintaining and improving the performance of banks. The Basel Committee for Banking Supervision pointed out that effective corporate governance practices are critical to achieving and maintaining public trust and confidence in the banking system. This mechanism is also very important for the banking sector and the economy as a whole. Considering the first characteristic of the banking industry as an intermediary institution, in carrying out its business activities, it depends on public funds and trust from both within and outside the country. Apart from these characteristics, the banking industry is a highly regulated industry considering that the business activities carried out by the banking industry are full of various risks that must be faced, one of which is liquidity risk (KNKG, 2004).

GCG must be implemented by banks in Indonesia, since Bank Indonesia issued Bank Indonesia Regulation (PBI) No.8/4/PBI/2006 dated 30 January 2006 concerning Implementation of Good Corporate Governance for Commercial Banks as amended by PBI No.8/14/ PBI/2006 dated 5 October 2006 and Circular Letter of Bank Indonesia (SEBI) No. 9/12/DPNP dated 30 May 2007 concerning the Implementation of Good Corporate Governance for Commercial Banks. Then since 2016, the regulations regarding GCG refer to the Financial Services Authority Regulation (POJK) No. 55/POJK.03/2016, there are several mechanisms in carrying out GCG, especially in 


\section{Indira Nuansa Ratri}

Indonesia, one of which is the existence of a board of commissioners, where the board of commissioners has responsibility for bank operations and acts as a monitor also advisor to top management of the bank (Phatan and Faff, 2013)

The board of commissioners as one of the effective GCG mechanisms is also an important consideration for banks around the world. This was driven by various reform efforts, one of which was that bank managers gained greater control over business decision making, as government intervention had decreased and bank ownership structures had diversified. This is not balanced with banking market control, so market control is still underdeveloped. Therefore, the board's role, especially in terms of size, can be a key mechanism for monitoring and advising bank managers (Gafoor, Mariappan and Thyagarajan, 2018).

Empirical evidence conducted by previous researchers shows that liquidity risk has a significant positive and negative effect on banking performance. Therefore, banks need to maintain their liquid assets to maintain their performance (Hunjra et al., 2020). A similar study was also reviewed by (Abdelaziz, Rim and Helmi, 2020), which stated that liquidity risk had a negative impact on bank profitability. This research was conducted by taking samples from banks in the MENA region. Research conducted by Belkhir, (2009) regarding the effect of board size on banking performance shows that the more the number of board members in a bank, the banking performance will also increase.

Contrary to research conducted by Phatan and Faff (2013), which states that the size of the board has a negative effect on banking performance related to the issue of free riders. The development of research related to good corporate governance was also carried out by Liang, Xu and Jirapon (2013), which examined the effect of the characteristics of the board of commissioners on banking performance that affect motivation and ability to perform supervisory and advisory duties, which in turn can improve bank performance. Gafoor, Mariappan and Thyagarajan (2018) also tested the effect of board characteristics on bank performance in Indian banking. The results of research conducted by Gafoor, Mariappan and Thyagarajan (2018) show that board size, the proportion of financial experts, and the number of members of the board attending the meeting have a positive effect on bank performance.

Previous research only focused on the effect of each liquidity risk on bank performance and testing the board's characteristics on bank performance. Previous research has not included and directly tested two variables, namely liquidity risk and characteristics of board members on bank performance. So this study is intended to examine the effect of liquidity risk on bank performance, then examine the moderating effect of board characteristics influence of liquidity risk on bank performance to fill the research gap and to determine whether 
characteristics of the board can have a direct or indirect impact on the risk of liquidity owned by banks to improve their performance.

\section{LITERATURE REVIEW AND HYPOTHESES}

\section{Bank Performance}

Firm performance is something that the firm achieves within a certain period. This information is needed to evaluate the performance achieved by the firm's management in the past and for consideration in preparing the firm's future plans (Sudana, 2011). In this study, bank performance is calculated using the profitability ratio, namely the return on assets. Profitability is the firm's ability to generate profits by using or utilizing assets owned by a firm in one period. ROA is a ratio used to measure the firm's ability to earn profits or rate of return by utilizing the total assets owned by the bank. The higher the ROA value, the more efficient the bank utilises all its assets to generate profits and improve performance.

\section{Bank Liquidity}

A healthy bank has to be able to determine the liquidity level required by Bank Indonesia in order to avoid liquidity risk. According to the Indonesian Bankers Association (2016), liquidity in banking is how the bank can meet the demand for funds obligations, both from depositors/fund owners and debtors/fund users. Research conducted by (Susanthi, 2010) uses the ratio of loans to total assets to calculate the level of liquidity. The higher the loan to total asset ratio value, the higher the amount of credit disbursed by the bank to customers.

\section{Board Characteristics}

The Board of Commissioners is part of a control system internal established to prevent or reduce agency problems between shareholders and management due to the separation between ownership and control (Belkhir, 2008). The board of commissioners is also tasked with ensuring the implementation of GCG principles in banking business activity at all levels of the bank's organization. Characteristics of the board are important because they have several characteristic aspects, including the size and function of the board, that can affect the ability of the board to provide advice and monitor the directors effectively.

\section{Board Size}

POJK Number 55/POJK.03/2016 concerning Implementation of Governance for Commercial Banks regarding Commissioners, Article 23 states that (1) Banks are required to have at least 3 (three) board members and at most equal to the number of members of directors. (2) The members of the board, as referred to in paragraph (1), are at least 1 (one) person be domiciled in Indonesia. (3) The board must be led by the president commissioner or the main 


\section{Indira Nuansa Ratri}

commissioner. The duties and responsibilities of the board in article 30 state that the board must carry out their duties and responsibilities independently. The general guidelines for good corporate governance in Indonesia, KNKG (2006) provide basic principles as a reference so that the implementation of the duties of the board can run effectively. The following principles need to be considered: (1) The board's composition must allow for effective, precise and fast decision making, and can act independently; (2) Members of the board must be professional with integrity and have the ability to carry out their functions properly, including ensuring that the Board of Directors has taken into account the interests of all stakeholders; (3) The supervisory and advisory function of the Board of Commissioners includes preventive action, corrective action, up to temporary dismissal.

\section{Board Meeting}

The characteristics of the board can be seen from the functions or activities of the board, which are described by the number of board meetings. The board meeting takes into account the number of annual board meetings. An excessively high frequency and attendance rate of board meetings can be considered as indicators of board ineffectiveness. In Indonesia, the board meeting is also regulated in the Financial Services Authority Regulation Number 55/POJK.03/2016 concerning the Implementation of Governance for Commercial Banks in article 37.

\section{Liquidity on Bank Performance}

In the history of banking crises that have occurred so far, bank liquidity crises are one of the main causes of bank defaults for most of their obligations. Lack of liquidity in banks can result in banks not being able to meet depositors' demands when they want to withdraw their deposits (Hunjra et al., 2020). If that condition happens, depositors' confidence in the bank will decrease, which can lead to a worse situation, namely bank rush, which is the simultaneous withdrawal of deposits by depositors. Banks with sufficient liquidity can carry out their intermediation function properly, store and manage deposits from the public, and distribute them to other parties in the form of credit (Abdelaziz, Rim and Helmi, 2020). The smooth running of the bank's business activities will have an impact on improving the bank's performance.

\section{$H_{1}$ : Bank liquidity has a positive effect on bank performance}

\section{Liquidity on Bank Performance Moderated by Board Size}

Board size weakens the positive influence of liquidity on bank performance. This means that the positive influence of bank liquidity on bank performance is getting weaker if a bank has a higher number or size of board of commissioners. Overall, the board of commissioners plays an important role in bank governance, especially in carrying out supervisory and advisory functions. This will then affect the resulting bank performance (Liang, XU and Jirapon, 2013). 
Thus, the larger size of the board can weaken it because a large size of the board can make it ineffective in every discussion carried out so that it does not reach the agreed consensus. In the end, banks with a large board are unable to communicate, coordinate, and make appropriate decisions regarding the optimal percentage of total loans disbursed, which will reduce banks' performance.

$\mathrm{H}_{2}$ : The large size of the board weakens the positive influence of liquidity on bank performance

\section{Liquidity on Bank Performance Moderated by Board Meeting}

Board of commissioners meeting weakens the positive influence of liquidity on bank performance. This means that the positive influence of bank liquidity on bank performance gets weaker if the board of commissioners in a bank has a very high intensity of meetings. This is because when banks hold meetings with a frequent or high enough intensity, it shows that the resulting meetings are inefficient and do not produce a consensus that has been determined and agreed upon (Brick and Chidambaran, 2010). In addition, the higher or more frequent the intensity of a meeting being held will make the attendance rate of the board decrease. The board will be asked to attend more scheduled meetings. Thus, banks' benefits from high meetings held are significantly eroded by lower director attendance (Gray, Harymawan and Nowland, 2016). This increase in the frequency of meetings itself causes directors to be too busy so that the benefits of the high number of meetings being held will be eroded (Gray, Harymawan and Nowland, 2016).

$\mathrm{H}_{3}$ : High board meeting weakens the positive influence of liquidity on bank performance

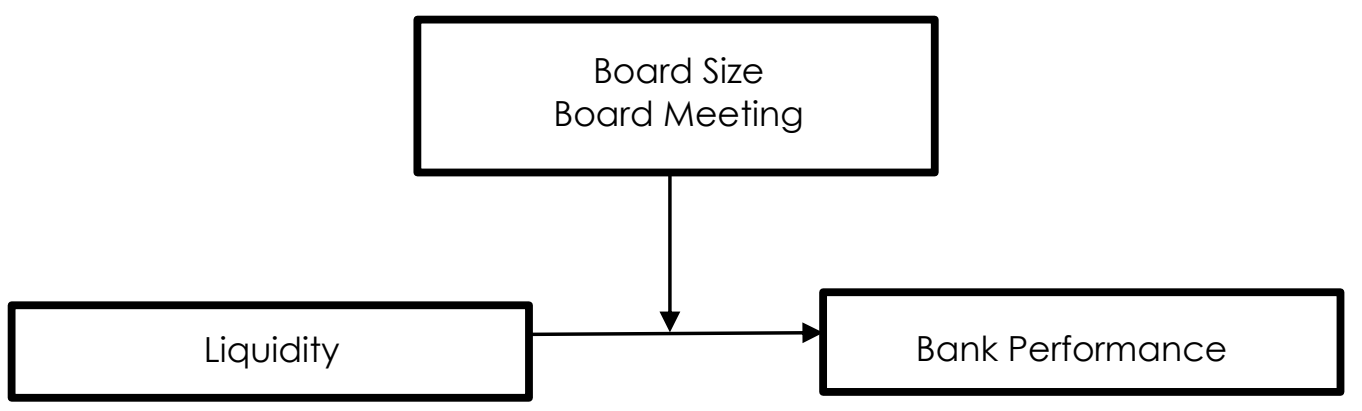

Figure 1.

Model Analysis

\section{RESEARCH METHODS}

\section{Population and Research Sample}

This study used a sample of conventional commercial banks listed on the Indonesia Stock Exchange in the 2014-2019. The sampling method in this study was purposive (Cooper and Schindler, 2014) with two criteria. First, a bank is listed on the Indonesia Stock Exchange and operating in the 2014-2019. Second, banks have financial statements accompanied by complete data related to the variables used in the research in 2014 to 2019. 


\section{Data Collection Type}

This study used secondary data obtained from the financial statements and annual reports of conventional banks listed on the Indonesia Stock Exchange for 2014-2019. All financial reports and annual reports were obtained from the Indonesia Stock Exchange website and related bank websites and then researched.

\section{Operational Definitions and Research Variables}

This study used the dependent variable in the form of bank performance, independent variables in the form of bank liquidity; board size; board meeting; and control variables in the form of bank size and growth of Gross Domestic Product (GDP). The operational definitions and research variables used in this study are summarized in table 1.

Table 1.

Operational Definitions and Research Variables

\begin{tabular}{|c|c|c|}
\hline Variable & Definition & Measurement \\
\hline $\begin{array}{l}\text { Bank } \\
\text { Performance }\end{array}$ & $\begin{array}{l}\text { Something the bank achieves in a } \\
\text { certain period }\end{array}$ & $R O A_{i, t}=\frac{E A T_{i, t}}{\text { Total Asset }_{i+}}$ \\
\hline Bank Liquidity & $\begin{array}{l}\text { The ability of a bank to meet the } \\
\text { demand for funds obligations, } \\
\text { both depositors/fund owners and } \\
\text { debtors/fund users. (Indonesian } \\
\text { Bankers Association, 2016) }\end{array}$ & $\begin{array}{l}\text { Loan to Total Assets } \text { Ratrio }_{i, t} \\
=\frac{\text { Total Credit }_{i, t}}{\text { Total Asset }_{i, t}}\end{array}$ \\
\hline Board Size & $\begin{array}{l}\text { The number of members of the } \\
\text { board at the bank. }\end{array}$ & BOARD.SIZE $\mathrm{E}_{\mathrm{i}, \mathrm{t}}=\sum$ board size $\mathrm{e}_{\mathrm{i}, \mathrm{t}}$ \\
\hline Board Meeting & Number of annual board meeting. & Meeting $\mathrm{i}_{\mathrm{i}}=$ Lboard $_{\text {meeting }} \mathrm{i}, \mathrm{t}$ \\
\hline Bank Size & $\begin{array}{l}\text { The value of the total assets } \\
\text { owned by a bank (Tabak et al, } \\
\text { 2012) }\end{array}$ & Size $_{i, t}=\operatorname{Ln}(\text { total asset })_{i, t}$ \\
\hline GDP Growth & $\begin{array}{l}\text { The difference between nominal } \\
\text { GDP at constant prices in period } t \\
\text { and GDP at constant prices in } \\
\text { period t- } 1 \text { against GDP at constant } \\
\text { prices in the previous year }\end{array}$ & $G D P$ Growth $=\frac{G D P_{t}-G D P_{t-1}}{G D P_{t-1}}$ \\
\hline
\end{tabular}

\section{Method Analysis}

The data that has been collected was then processed and analyzed by statistical tests, which include: descriptive statistics, classical assumption tests, and hypothesis testing. This study used multiple linear regression to test the effect of the independent variable on the dependent variable. There are three equation models to test the hypothesis in this study, namely:

$$
\begin{aligned}
& R O A i, t=\alpha+\beta_{1} L_{i q} q_{i, t}+\beta_{2} S_{i z e} e_{i, t}+\beta_{3} G_{D P}+\varepsilon_{i, t} \\
& \text { ROA }_{i, t}=\alpha+\beta_{1} L_{i q} q_{i, t}+\beta_{2} \text { BOARD.SIZE }_{i, t}+\beta_{3} \text { Liq }_{i, t}{ }^{*} \text { BOARD.SIZE } E_{i, t}+\beta_{4} S_{i z e_{i, t}}+\beta_{5} \text { GDP }_{t}+\varepsilon_{i, t} \\
& \text { ROA }_{i, t}=\alpha+\beta_{1} \text { Liq }_{i, t}+\beta_{2} \text { Meeting }_{i, t}+\beta_{3} \text { Liq }_{i, t} * \text { Meeting }_{i, t}+\beta_{4} \text { Size }_{i, t}+\beta_{5} \text { GDP }_{t}+\varepsilon_{i, t}
\end{aligned}
$$

Explanation: 
ROA $i, t=$ performance of bank $i$ in period $t$. Liq $i, t=$ liquidity of bank $i$ in year $t$. BOARD.SIZE $i, t=$ board size of $\mathrm{i}$ in year $t$. Meeting $\mathrm{i}, t=$ number of board meeting in one year bank $\mathrm{i}$ in year $t$. Size $\mathrm{i}, \mathrm{t}=$ size of bank $\mathrm{i}$ in year $\mathrm{t}$. GDP $\mathrm{i}, \mathrm{t}=\mathrm{GDP}$ growth in period $\mathrm{t}$.

The next step was to test the determination hypothesis (R-Square). The significance of the coefficient is based on the $p$-value, sign ** shows significance at level $1 \%(p<0.01)$, and sign * shows significance at level $5 \%(p<0.05)$. Coefficient determination (R-square) measures the variance of how much the dependent variable can be explained by the independent variable in the equation model used. The coefficient determination has a value ranging from 0 to 1 . The higher the R-square, the higher ability of the independent variable to explain the dependent variable, and vice versa.

\section{RESULTS AND DISCUSSION}

Descriptive statistics in this study include the number of observations, average, standard deviation, minimum value, and maximum value of each variable which can be seen in Table 2. Based on Table 2, it appears that bank performance as measured by ROA has an average value of 0,0081 ; a minimum value of $-0,1173$ and the maximum value is 0,0313 . A low ROA value indicates a bank has poor performance or is experiencing a loss, and vice versa, a high ROA value indicates a high bank performance. Bank Liquidity variable has an average of 0,6114; maximum value of 0,8380 ; minimum value of 0,3441 . The minimum liquidity variable shows the low amount of credit disbursed compared to total assets owned by the bank and vice versa. The maximum value of bank liquidity shows the high amount of credit disbursed by the bank. The COMSIZE variable has an average of 5,0200. This variable itself shows the number of the board in a bank. The minimum COMSIZE value is 2,0000, which shows the lowest number of board size and vice versa. The maximum value of COMSIZE is 9,0000 shows the highest number of members of the board. MEETING variable has an average of 23,3900; the minimum value of MEETING is 0 ; maximum value of MEETING is 92 . The maximum value of MEETING indicates the high number of meetings held by members of the board, and vice versa. The minimum value indicates the low number of meetings held by members of the board.

\section{Table 2}

Statistics Description

\begin{tabular}{llllll}
\hline & N & Minimum & Maximum & Mean & Std. Dev \\
\hline ROA & 186 & $-0,1173$ & 0,0313 & 0,0081 & 0,0159 \\
LIQ & 186 & 0,3441 & 0,8380 & 0,6114 & 0,0885 \\
BOARDSIZE & 186 & 2,0000 & 9,0000 & 5,0200 & 1,9640 \\
MEETING & 186 & 0 & 91 & 23,2300 & 18,0970 \\
SIZE & 186 & 27,2226 & 34,8871 & 31,2325 & 1,8979 \\
GDP & 186 & 0,0048 & 0,0517 & 0,0422 & 0,0177 \\
\hline
\end{tabular}




\section{Indira Nuansa Ratri}

Table 3 shows the results of hypothesis testing using multiple linear regression to test the hypothesis on the three models used in the study. Model 1 shows that the bank liquidity variable (LIQ) has a significant positive effect on the bank performance (ROA). The control variable bank size (SIZE) has a significant positive effect on bank performance, while the GDP (GDP) variable has a negative effect on bank performance. Model 2 shows that board size weakens the positive effect of liquidity (LIQ) on the bank performance (ROA). Model 3 also shows that the number of meetings held by members of the board (MEETING) weakens the positive effect of liquidity (LIQ) on the bank performance (ROA).

Table 3

Hypothesis testing

\begin{tabular}{lccc}
\hline Variable & ROA & ROA & ROA \\
& Model 1 & Model 2 & Model 3 \\
\hline LIQ & 0.024 & 0.163 & 0.077 \\
BOARDSIZE & $(0.037)^{*}$ & $(0.000)^{* *}$ & $(0.000)^{* *}$ \\
LIQ*BOARDSIZE & & 0.030 & \\
& & $(0.000)^{* *}$ & \\
MEETING & & -0.184 & \\
LIQ*MEETING & & $(0.001)^{* *}$ & 0.001 \\
& & & $(0.001)^{* *}$ \\
SIZE & & & -0.002 \\
& & & $(0.001)^{* *}$ \\
GDP & 0.004 & 0.006 & 0.004 \\
& $(0.000)^{* *}$ & $(0.000)^{* *}$ & $(0.000)^{* *}$ \\
Intercept & -0.059 & -0.101 & -0.072 \\
& $(0.181)$ & $(0.059)$ & $(0.185)$ \\
R-Square & -0.141 & -0.274 & -0.171 \\
$\mathrm{~N}$ & $(0.000)$ & $(0.000)$ & $(0.000)$ \\
If & 0.290 & 0.373 & 0.349 \\
& 186 & 186 & 186 \\
\hline
\end{tabular}

() t value

** significance on $1 \%$

* significance on $5 \%$

\section{Effect of Liquidity on Bank Performance}

Table 3 shows that the liquidity variable has a significant positive effect on bank performance. This means that the more loans disbursed by banks calculated by LAR, the greater the distribution of funds to loans so that profits will increase. The increase in profit results in higher bank performance as measured by ROA. Banks with sufficient liquidity can carry out their intermediation function properly, store and manage deposits from the public, and distribute them to other parties in the form of credit. The standard used by Bank Indonesia for LAR is a maximum of $30 \%$. If the LAR of a bank is above or below the limit set by $\mathrm{BI}$, the bank, in this case, can be said to have not carried out its function as an intermediary properly. These results are also supported by several studies, Astohar (2009), which state that the LAR variable has a positive effect on ROA. Suyanto (2021); Huong, Nga and Oanh (2021)) also stated the same 
result. Most studies in Europe, Poposka and Trpkoski (2013) show that the greater the bank's liquidity, the higher the bank performance. This means that the higher the LAR up to a certain limit, the more funds will be channelled in the form of credit to increase interest income so that ROA also increases.

\section{The Effect of Liquidity on Bank Performance Moderated by Board Size}

Table 3 shows that the board size significantly weakens the positive effect of liquidity on bank performance. This means that the positive effect of bank liquidity on bank performance is getting weaker if a bank has a larger number or size of the board. Overall, the board of commissioners plays an important role in bank governance, especially in carrying out supervisory and advisory functions. This will then affect the resulting bank performance (Liang, $X U$ and Jirapon, 2013). The large size of the board can weaken the positive effect of liquidity on bank performance because a large board size can face greater problems in expressing the opinions of its members due to the limited time available during board member meetings. In addition, the higher the size of the board can be weakened because the large board size can make it ineffective in any discussions that are carried out so as not to reach the agreed consensus (Lipton and Lorsch, 1992; Yermack, 1996). In the end, banks with large board size are unable to communicate, coordinate, and make appropriate decisions regarding the optimal percentage of total loans disbursed, which will reduce the performance of banks. Jensen (1993) also stated that keeping the number of board members small can help improve bank performance.

\section{Effect of Liquidity on Bank Performance Moderated by Board Meeting}

Table 3 shows the board meeting significantly weakened the positive effect of liquidity on bank performance. This means that the positive effect of bank liquidity on bank performance is weaker if the board of commissioners in a bank has a very high intensity of meetings. When banks hold meetings with frequent or very high intensity, it shows that the resulting meetings are inefficient and do not produce a consensus that has been determined and will be agreed upon (Brick and Chidambaran, 2010). In addition, members of the board will be busier when the number of meetings held is higher when members of the board become busier, will make the attendance rate of the board decrease because they are asked to attend more scheduled meetings (Panicker and Upadhyayula, 2020; Gray, Harymawan and Nowland, 2016). This then causes the benefits obtained by banks from the high number of meetings held to be significantly eroded by the presence of a lower board of commissioners (Gray, Harymawan and Nowland, 2016). When the benefits derived from the high board meetings held are low, this will interfere with the bank in carrying out every task, resulting in a decline in 


\section{Indira Nuansa Ratri}

the bank's performance. Thus, the high number of meetings significantly weakens the positive effect of liquidity on bank performance.

\section{CONCLUSION}

Based on research conducted on conventional banks listed on the Indonesia Stock Exchange during the period 2014-2019 with three models tested using multiple linear regression, it shows that bank liquidity has a significant positive effect on bank performance. The higher the amount of credit disbursed, the higher the performance generated by the bank, as indicated by the calculation of ROA. In addition, this study shows that the board size weakens the positive effect of liquidity on bank performance. The higher the board size in a liquid bank, the lower the performance generated by the bank. This study also shows that the number of meetings of the board weakens the positive effect of liquidity on bank performance.

This study also provides several important implications for banking. Among others, banks need to pay attention to the level of liquidity they have to optimize bank performance and retain their customers. In addition, regarding bank governance, in particular, it is necessary to pay attention to the optimal number of board members to carry out their supervisory and advisory functions to the maximum to improve bank performance. The number of meetings held by banks also needs to be considered in corporate governance management so that the goal of improving bank performance can be achieved.

The limitation in this study is that the moderation used regarding the characteristics of the members of the board of commissioners only includes the board size and board so that it can be developed more broadly for future research.

\section{REFERENCES}

Abdelaziz, H., Rim, B. and Helmi, H. 2020. The interactional relationships between credit risk, liquidity risk and bank profitability in MENA region. Global Business Review.

Astohar, A. 2009. Analisis Faktor-Faktor Yang Mempengaruhi Profitabilitas Perbankan Di Indonesia (Studi pada Bank Domestik, Bank Campuran dan Bank Asing. Universitas Diponegoro.

Belkhir, M. 2008. Board of directors' size and performance in the banking industry. International Journal of Managerial Finance, 5(1).

Belkhir, M. 2009. Board structure, ownership structure and firm performance: evidence from banking. Applied financial economics, 19(19): 1581-1593. 
BI. (2006). Peraturan Bank Indonesia Nomor 8/14/PBI/2006 Tentang Pelaksanaan Good Corporate Governance bagi Bank Umum. Jakarta: Bank Indonesia.

Brick, I.E. and Chidambaran, N.K. 2010. Board meetings, committee structure, and firm value. Journal of corporate finance, 16(4): 533-553.

Cooper, D.R. and Schindler, P.S. 2014. Business Research Methods (12th ed.). The McGraw-Hill Companies.

Gafoor, C.P.A., Mariappan, V. and Thyagarajan, S. 2018. Board characteristics and bank performance in India. IMB Management Review, 30: 160-167.

Gray, S., Harymawan, I. and Nowland, J. 2016. Political and government connections on corporate boards in Australia: Good for business? Australian Journal of Management, $41(1): 3-26$.

Halling, M. and Hayden, E. 2006. Bank failure prediction: a two-step survival time approach.

Hunjra, A.I., Mehmood, A., Nguyen, H.P. and Tayachi, T. 2020. Do firm-specific risks affect bank performance? International Journal of Emerging Markets.

Huong, T.T.X., Nga, T.T.T. and Oanh, T.T.K. 2021. Liquidity risk and bank performance in Southeast Asian countries: a dynamic panel approach. Quantitative Finance and Economics, 5(1): $111-133$.

Jensen, M. 1993. The Modern Industrial Revolution, Exit, and The Failure of Internal Control Systems. Journal of Finance, 48: 831-880.

KNKG. 2004. Pedoman Good Corporate Governance Perbankan Indonesia. Jakarta: Komite Nasional Kebijakan Governance

Liang, Q., XU, P. and Jirapon, P. 2013. Board characteristics and Chinese bank performance. Journal of Banking and Finance, 37: 2953-2968.

Lipton, M. and Lorsch, J.W. 1992. A Modest Proposal for Improved Corporate Governance. The Business Lawyer, 48: 59-77.

OJK. (2016). Peraturan Otoritas Jasa Keuangan Nomor 55/POJK.03/2016 tentang Penerapan Tata Kelola Bagi Bank Umum. Jakarta: Otoritas Jasa Keuangan

Panicker, V.S. and Upadhyayula, R.S. 2020. Limiting role of resource dependence: an examination of director interlocks, board meetings and family ownership. Cross Cultural 
Indira Nuansa Ratri

and Strategic Management.

Phatan, S. and Faff, R. 2013. Does board structure in banks really affect their performance? Journal of Banking and Finance, 37: 1573-1589.

Poposka, K. and Trpkoski, M. 2013. Secondary model for bank profitability management-test on the case of Macedonian banking sector. Research Journal of Finance and Accounting, 4(6): 216-225.

Sudana, I.M. 201 1. Manajemen Keuangan Perusahaan: Teori dan Praktik. Jakarta: Erlangga.

Susanthi, A. 2010. Pengaruh Loan to Deposit ratio, Capital Adequacy Ratio, dan Leverage Management terhadapProfitabilitaspada PT Bank Pembangunan Daerah Bali Kantor Pusat Denpasar. Universitas Udayana.

Suyanto, S. 2021. The Effect of Bad Credit and Liquidity on Bank Performance in Indonesia. The Journal of Asian Finance. Economics and Business, 8(3): 451-458.

Wijayanti, E. and Mardiana, M. 2020. Loan growth and bank profitability of commercial banks in indonesia. AKUNTABEL, 17(1): 38-52.

Yermack, D. 1996. Higher market valuation of companies with a small board of directors. Journal of Financial Economics, 40: 185-211. 